\title{
Diurnal Fluctuation in Tissue Nitrate Concentration of Field-grown Leafy Greens at Two Latitudes
}

\author{
Haly L. Neely and Richard T. Koenig ${ }^{1}$ \\ Department of Crop and Soil Sciences, Washington State University, \\ Pullman, WA 99164-6420
}

Carol A. Miles

Department of Horticulture and Landscape Architecture, Washington State University, Northwestern Washington Research and Extension Center, 16650 State Route 536, Mount Vernon, WA 98273

\author{
Teresa C. Koenig \\ Department of Horticulture and Landscape Architecture, Washington State \\ University, Pullman, WA 99164-6414
}

\section{Meriam G. Karlsson \\ Department of High Latitude Agriculture, School of Natural Resources and Agricultural Sciences, University of Alaska Fairbanks, AK 99775}

Additional index words. Lactuca sativa, Spinacia oleracea, lettuce, spinach, fertilizer

\begin{abstract}
Tissue nitrate $\left(\mathrm{NO}_{3}\right)$ concentration (TNC) in leafy greens generally decreases with increasing light intensity and photoperiod in controlled environment studies. Harvesting late in the day has been recommended as a way to produce leafy greens with lower TNC, although data from field research do not support this recommendation. This study investigated the effect of time of day of harvest on TNC in lettuce (Lactuca sativa L.) and spinach (Spinacia oleracea L.) grown in the field during the summer at Pullman, WA (lat. $46^{\circ} \mathrm{N}$ ) and Fairbanks, AK (lat. $64^{\circ} \mathrm{N}$ ). Whole plants were sampled every 2 h on three separate, 24-h harvest dates at each latitude. Plants were dried, ground, and analyzed for $\mathrm{NO}_{3}-\mathrm{N}$. At the high-latitude location, TNC decreased linearly during the day (1000 to $2300 \mathrm{HR}$ ) on all three dates for spinach and one for lettuce. At the low-latitude location, TNC decreased linearly during the day (1000 to $1900 \mathrm{HR}$ ) on one date and increased linearly during the night (2000 to $0400 \mathrm{HR})$ on two dates for lettuce. The TNC (average 287 to $607 \mathrm{mg} \mathrm{NO}$-N/kg fresh weight for lettuce and 141 to $189 \mathrm{mg}$ $\mathrm{NO}_{3}-\mathrm{N} / \mathrm{kg}$ fresh weight for spinach) and magnitude of diurnal fluctuation (generally less than $25 \%$ ) should not pose a human health risk regardless of when plants are harvested.
\end{abstract}

Leafy green vegetables are an important source of $\mathrm{NO}_{3}{ }^{-}$in the human diet (Maynard et al., 1976; Santamaria et al., 1999; Vogtmann et al., 1984). Vegetables with a tendency to accumulate high concentrations of $\mathrm{NO}_{3}{ }^{-}$include lettuce, spinach, Swiss chard (Beta vulgaris var. cicla L.), and radish (Raphanus sativus L.). These species are considered nitrophilic (Vogtmann et al., 1984) because of luxury nitrogen $(\mathrm{N})$ consumption that may lead to its accumulation in excess of the amount required for maximum growth (Grindlay, 1997).

Received for publication 12 Aug. 2010. Accepted for publication 4 Oct. 2010.

Ms. Neely's program was funded in part by the Glen D. Franklin Endowed Graduate Fellowship in the Department of Crop and Soil Sciences.

We thank Ms. Kelsi Alcott for performing tissue analyses for this study.

This research was conducted by the first author in partial fulfillment of the requirements for the degree of Master of Science in Soil Science.

${ }^{1}$ To whom reprint requests should be addressed; e-mail richk@wsu.edu.
Plants grown under conditions of high light intensity and long photoperiod often have lower TNC (Maynard et al., 1976) attributable, in part, to light activation of nitrate reductase activity (Kaiser and Huber, 2001; Solomonson and Barber, 1990). In a global survey of fieldgrown vegetables, Roorda van Eysinga (1984) reported that several crops, including lettuce and spinach, grown in areas of high light intensity had lower TNC than those same crops grown in areas with low light intensity. Increased light intensity decreased TNC in spinach (Steingrover et al., 1986), oat (Avena sativa L.), rye (Secale cereale L.) (Chen and Ries, 1969), and corn (Zea mays L.) (Hageman et al., 1961) seedlings. Leaf blade $\mathrm{NO}_{3}-\mathrm{N}$ concentration in spinach grown in a controlled environment at $145 \mu \mathrm{mol} \cdot \mathrm{m}^{-2} \cdot \mathrm{s}^{-1}$ during the light period increased from $\approx 1100$ to $2300 \mathrm{mg}$ $\mathrm{NO}_{3}-\mathrm{N} / \mathrm{kg}$ fresh weight during the dark period when sampled every $2 \mathrm{~h}$ (Steingrover et al., 1986). Cantliffe (1972a) reported that spinach grown in a controlled environment under light levels of $\approx 120 \mu \mathrm{mol} \cdot \mathrm{m}^{-2} \cdot \mathrm{s}^{-1}$ had more than twice the TNC than those grown under $\approx 320$ $\mu \mathrm{mol} \cdot \mathrm{m}^{-2} \cdot \mathrm{s}^{-1}$. Spinach TNC was reduced from 2000 to $700 \mathrm{mg} \mathrm{NO}-\mathrm{N} / \mathrm{kg}$ fresh weight when light intensity was increased from 200 to $800 \mu \mathrm{mol} \cdot \mathrm{m}^{-2} \cdot \mathrm{s}^{-1}$ (Proietti et al., 2004). Either increases in light intensity or longer photoperiods decreased TNC in wheat (Triticum aestivum L.) (Harper and Paulsen, 1968). Cantliffe (1972b) found that the TNC of spinach grown for $12 \mathrm{~h}$ in light of $\approx 500$ $\mu \mathrm{mol} \cdot \mathrm{m}^{-2} \cdot \mathrm{s}^{-1}$ was $22 \%$ lower than spinach exposed to $6 \mathrm{~h}$ of light at the same intensity.

To lower TNC in leafy greens grown for human consumption, researchers have recommended harvesting crops near the end of the photoperiod (Cantliffe, 1972a; Maynard et al., 1976; Steingrover et al., 1982). However, this recommendation is based on studies conducted in growth chamber or greenhouse environments. In a field study, Weightman et al. (2006) found no consistent trends in TNC when sampling field-grown lettuce at 3-h intervals from 0700 to $2200 \mathrm{HR}$. In fact, TNC was often lower at 0700 and $1000 \mathrm{HR}$ compared with 1600 HR. The objective of this study was to determine the influence of time of day of harvest on TNC in summer-grown lettuce and spinach at two latitudes with different light intensities and photoperiods.

\section{Materials and Methods}

Study sites and preparation. One study site was located at the Washington State University (WSU) Tukey Organic Research Farm (lat. $46^{\circ} 43^{\prime} \mathrm{N}$, long. $117^{\circ} 10^{\prime} \mathrm{W}$ ) in a Palouse silt loam (fine-silty, mixed, superactive, mesic Pachic Ultic Haploxeroll). The other site was located at the University of Alaska Fairbanks (UAF) Experiment Farm (lat. 64 $86^{\prime} \mathrm{N}$, long. $147^{\circ} 68^{\prime} \mathrm{W}$ ) in a Tanana mucky silt loam (coarse-loamy, mixed, superactive, subgelic Typic Aquiturbels). Both sites featured a randomized complete block experiment design with four replications. Plot size at WSU was $1.2 \mathrm{~m}$ wide $\times 7.6 \mathrm{~m}$ long $\left(9.1 \mathrm{~m}^{2}\right)$ with five rows of plants. Plot size at UAF was $0.6 \mathrm{~m}$ wide $\times 6.1 \mathrm{~m}$ long $\left(3.7 \mathrm{~m}^{2}\right)$ with three rows of plants.

At WSU, compost was applied at $\approx 56 \mathrm{~kg}$ total N/ha and incorporated with a tractordriven tiller. At UAF, a bed shaper-cultivator created raised beds. Compost was not available at the UAF site. Fishmeal was applied at WSU (8N-1.3P-0K; Peaceful Valley Farm Supply Inc., Grass Valley, CA) and at UAF (9N-2P-0K; Pro-Pell-It!; Marion Ag. Services, Inc., Aurora, OR) at $168 \mathrm{~kg}$ total N/ha. The fishmeal was broadcast by hand and incorporated with a rake to a depth of $5 \mathrm{~cm}$ several days before seeding or transplanting at both sites.

Soil samples were taken with a $2-\mathrm{cm}$ diameter probe at depths of 0 to $15 \mathrm{~cm}, 15$ to $30 \mathrm{~cm}$, and 30 to $60 \mathrm{~cm}$ after compost application at WSU but before planting or fishmeal application at both sites. Soil at both sites was sampled again immediately after the last harvest. Separate samples were collected from each replication with two soil cores combined for each replication. Samples for both sites were sent to a commercial soil 
testing laboratory and analyzed for $\mathrm{KCl}$ extractable $\mathrm{NO}_{3}-\mathrm{N}$ and $\mathrm{NH}_{4}-\mathrm{N}$ by colorimetric analysis in a continuous flow analyzer, $\mathrm{pH}$ (1:10 soil:water ratio by glass electrode), and organic matter by dry combustion.

'Cracoviensis' lettuce and 'Giant Winter' spinach were selected based on performance in previous research conducted at the WSU site (Ott et al., 2008). At WSU, both crops were seeded directly into soil on 13 May 2009 at $20 \mathrm{~cm}$ within-row spacing and rows spaced $20 \mathrm{~cm}$ apart. After emergence, plants were thinned to one per space. One line of drip tape irrigated each row twice a week at $\approx 2.5 \mathrm{~cm} /$ irrigation. At UAF, plant spacing was $20 \mathrm{~cm}$ within the row and $25 \mathrm{~cm}$ between rows. Lettuce was planted in a greenhouse on 16 May 2009 and transplanted into the field on 9 June. As a result of problems with greenhouse germination, spinach was direct-seeded on 9 June 2009. Two lines of drip tape were used to irrigate three rows of plants five times a week ( $\approx 0.5 \mathrm{~cm} /$ irrigation). At both locations, weeds were controlled by hand removal. Light intensity was measured every 15 min from planting through harvest using a photosynthetically active radiation $(P A R)$ sensor (Hobo S-LIA-M003; Onset, Bourne, MA) and recorded with a data logger (Hobo Micro Station S-LIAM003, H21-002; Onset).

Tissue sampling and processing. Tissue samples were collected every $2 \mathrm{~h}$ during three separate, 24-h periods at each location. Harvests always started at $1000 \mathrm{HR}$ and ended at 0800 HR the next day. At WSU, two plants were collected from each plot at each harvest on 12 June, 18 June, and 24 June 2009. At UAF, harvest dates were 2 July, 7 July, and 10 July 2009. As a result of a limited number of plants, only one plant was harvested per plot on each date at UAF. Lettuce plants had bolted by the third harvest at UAF.

At harvest, plants were cut $\approx 3 \mathrm{~cm}$ below the soil surface, placed in labeled plastic bags, and transported from the field to the laboratory within $1 \mathrm{~h}$. Roots and damaged leaves were removed from plants. Plants were rinsed with deionized water to remove soil, blotted dry with paper towels, and weighed. Samples were placed in paper sacks, dried at $80^{\circ} \mathrm{C}$ for at least $48 \mathrm{~h}$, and weighed again for data correction.

Oven-dried tissue was ground using a mortar and pestle. To extract $\mathrm{NO}_{3}-\mathrm{N}, 0.4 \mathrm{~g}$ of ground tissue was transferred to a $50-\mathrm{mL}$ vial to which $40 \mathrm{~mL}$ of $0.025 \mathrm{M} \mathrm{Al}_{2}\left(\mathrm{SO}_{4}\right)_{3} \mathrm{ex}-$ tracting solution was added. If $0.4 \mathrm{~g}$ was not available, all of the ground tissue was transferred and the exact weight recorded. Vials were capped and placed on an oscillating shaker for $30 \mathrm{~min}$. The solution was filtered through a Whatman \#2 paper and refrigerated until analysis.

Nitrate concentration was measured using an ion selective nitrate electrode (Orion Model 9700 BN Ionplus; Thermo Electron Corporation, Waltham, MA). The electrode was calibrated according to manufacturer recommendations using standards with concentrations of $1.4,14$, and $140 \mathrm{mg} \mathrm{NO}-\mathrm{N} / \mathrm{L}$ in the same matrix solution as the tissue extracts. Approximately $30 \mathrm{~mL}$ of $20{ }^{\circ} \mathrm{C}$ extract was poured into a $100-\mathrm{mL}$ beaker with a magnetic stir bar, and the extract was stirred at the same rate as the standards. Electrode drift was monitored by reading the midrange standard every six samples. The electrode was recalibrated if the reading deviated by $10 \%$ or greater from the standard concentration.

Whole-plant TNC on a fresh weight basis was calculated and plotted as a function of time for each harvest at each site. Data were analyzed using the PROC MIXED procedure in SAS (SAS Inst., Cary, NC). Because harvests occurred on separate days at each site, data were analyzed separately by site. Linear regression analysis (PROC REG) was used to test for the presence of significant trends in TNC over time. The night period was defined as $P A R 100 \mu \mathrm{mol} \cdot \mathrm{m}^{-2} \cdot \mathrm{s}^{-1}$ or less. Because plant sampling started at $1000 \mathrm{HR}$ each day at both locations, for the purposes of regression analysis, the day period was defined as 1000 to 2300 HR for Fairbanks and 1000 to 1900 HR for Pullman. Night periods were 2400 to 0500 HR at Fairbanks and 2000 to 0400 HR at Pullman.

\section{Results}

Available $\mathrm{N}$ in the top $60 \mathrm{~cm}\left(\mathrm{NO}_{3}+\mathrm{NH}_{4}\right.$ at $0-$ to $30-\mathrm{cm}$ depth, $\mathrm{NO}_{3}$ at $30-$ to $60-\mathrm{cm}$ depth) of soil was not significantly different between sites and averaged $61 \mathrm{~kg} \mathrm{~N} /$ ha before fish meal application and $136 \mathrm{~kg} \mathrm{~N} /$ ha after the third harvest (Table 1). The average maximum light intensity was $1480 \mu \mathrm{mol} \cdot \mathrm{m}^{-2} \cdot \mathrm{s}^{-1}$ at UAF and $1940 \mu \mathrm{mol} \cdot \mathrm{m}^{-2} \cdot \mathrm{s}^{-1}$ at WSU. The UAF site had $\approx 5 \mathrm{~h}$ of $0 \mu \mathrm{mol} \cdot \mathrm{m}^{-2} \cdot \mathrm{s}^{-1} \cdot \mathrm{d}^{-1}$ $P A R$ (Fig. 1), although there was always sufficient light to see throughout the 24-h sampling period. The WSU site had $\approx 8 \mathrm{~h}$ of $0 \mu \mathrm{mol} \cdot \mathrm{m}^{-2} \cdot \mathrm{s}^{-1} \cdot \mathrm{d}^{-1} P A R$ (Fig. 2). Weather conditions were mostly clear on all three harvest days at UAF. At WSU, clouds increased after $1200 \mathrm{HR}$ on 12 June and 18 June 18 partly cloudy. Sky conditions generally are reflected in $P A R$ measured at each location (Figs. 1 and 2).

Average fresh weight yield was 65 and $73 \mathrm{~g} /$ plant for lettuce at UAF and WSU, respectively. Average fresh weight yield was 9 and $57 \mathrm{~g} /$ plant for spinach at UAF and WSU, respectively. The low fresh weight yield for spinach at UAF was as a result of direct seeding less than 1 month before harvest started. Average TNC at UAF was $607 \mathrm{mg}$ $\mathrm{NO}_{3}-\mathrm{N} / \mathrm{kg}$ fresh weight for lettuce and 189 $\mathrm{mg} \mathrm{NO}_{3}-\mathrm{N} / \mathrm{kg}$ fresh weight for spinach. At WSU, average TNC was $287 \mathrm{mg} \mathrm{NO}-\mathrm{N} / \mathrm{kg}$ fresh weight for lettuce and $141 \mathrm{mg} \mathrm{NO}-\mathrm{N} /$ $\mathrm{kg}$ fresh weight for spinach.

Table 1. Pre-fertilization and post-harvest soil test data for study sites at the University of Alaska, Fairbanks (UAF) and Washington State University (WSU), Pullman.

\begin{tabular}{|c|c|c|c|c|c|c|c|c|c|}
\hline & \multirow{2}{*}{$\begin{array}{c}\text { Depth } \\
(\mathrm{cm})\end{array}$} & \multicolumn{2}{|c|}{$\mathrm{NO}_{3}-\mathrm{N}\left(\mathrm{kg} \cdot \mathrm{ha}^{-1}\right)$} & \multicolumn{2}{|c|}{$\mathrm{NH}_{4}-\mathrm{N}\left(\mathrm{kg} \cdot \mathrm{ha}^{-1}\right)$} & \multicolumn{2}{|c|}{$\mathrm{pH}$} & \multicolumn{2}{|c|}{ Organic matter $(\%)$} \\
\hline & & UAF & WSU & UAF & WSU & UAF & WSU & UAF & WSU \\
\hline \multirow[t]{2}{*}{ Pre-fertilization } & $0-30$ & 24.7 & 14.3 & 13.5 & 16.6 & 7.53 & 6.67 & 5.57 & 3.60 \\
\hline & $30-60$ & 42.6 & 10.1 & & & & & & \\
\hline \multirow[t]{2}{*}{ Post-harvest } & $0-30$ & 70.3 & 77.3 & 8.1 & 34.5 & 6.93 & 6.25 & 5.86 & 3.75 \\
\hline & $30-60$ & 42.6 & 40.4 & & & & & & \\
\hline
\end{tabular}

At each site, lettuce consistently had higher TNC than spinach. At UAF, there were no significant main effects of harvest time or interaction between species and harvest time on TNC. TNC decreased linearly during the day (1000 to $2300 \mathrm{HR}$ ) on all three dates for spinach and one for lettuce (Fig. 1). At WSU, there was no significant main effect of harvest time or interaction between species and harvest time for the 12 to 13 June sampling. For the remaining two harvests, there was a significant main effect of harvest time and interaction between time and species $(P \leq 0.05)$. Tissue $\mathrm{NO}_{3}-\mathrm{N}$ concentration decreased linearly during the day (1000 to $1900 \mathrm{HR}$ ) on one date and increased linearly during the night (2000 to $0400 \mathrm{HR}$ ) on two dates for lettuce (Fig. 2).

\section{Discussion}

In principle, our results support the recommendation to harvest late in the day to produce leafy greens with lower TNC (Cantliffe, 1972a; Maynard et al., 1976; Steingrover et al., 1982). However, although in the majority of cases TNC decreased linearly with time during the day and increased at night, the magnitude (slope) of change was relatively small with maximum diurnal changes of less than $25 \%$ compared with controlled environment studies in which TNC varied by as much as $100 \%$ to $300 \%$ diurnally or under different light intensities (Cantliffe 1972a; Proietti et al., 2004; Steingrover et al., 1986). In contrast, in field-grown lettuce Weightman et al. (2006) also reported that TNC did not follow a diurnal pattern if plants were sampled at 3-h intervals from 0700 to $2200 \mathrm{HR}$, and TNC was often lower at 0700 and $1000 \mathrm{HR}$ than at $1600 \mathrm{HR}$. Although our results indicate some diurnal change in the TNC of lettuce and spinach, the trends are not as apparent as those from controlled-environment studies in which a clear diurnal pattern in TNC is reported (Maynard et al., 1976; Steingrover et al., 1986).

Light intensity and duration in this field study were considerably higher than in controlled environment studies for which clear diurnal changes in TNC are reported. For example, Cantliffe (1972a) reported that spinach grown in a controlled environment under light levels of $\approx 120 \mu \mathrm{mol} \cdot \mathrm{m}^{-2} \cdot \mathrm{s}^{-1}$ had more than twice the TNC compared with those grown under $\approx 320 \mu \mathrm{mol} \cdot \mathrm{m}^{-2} \cdot \mathrm{s}^{-1}$. Spinach TNC was reduced from 2000 to $700 \mathrm{mg} \mathrm{NO}-\mathrm{N} / \mathrm{kg}$ fresh weight when light intensity was increased from 200 to $800 \mu \mathrm{mol} \cdot \mathrm{m}^{-2} \cdot \mathrm{s}^{-1}$ (Proietti et al., 2004). The controlled environment light intensities are well below the maximum $P A R$ 


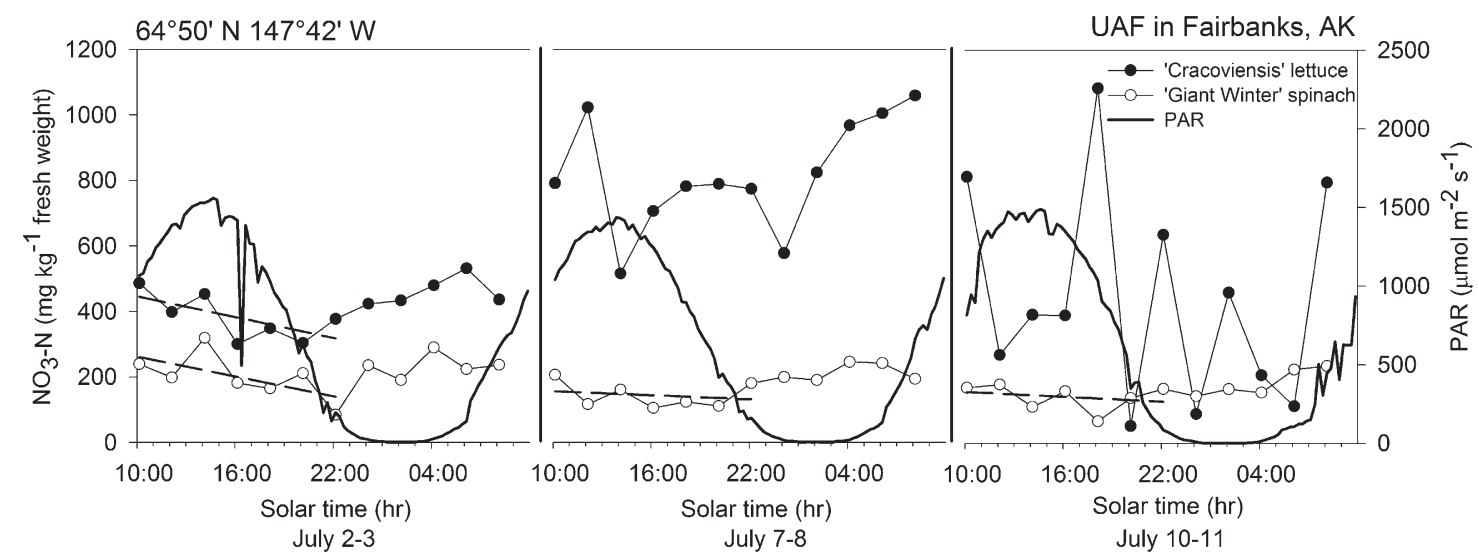

Fig. 1. Variations in photosynthetically active radiation $(P A R)$ and tissue nitrate concentration (TNC) in lettuce and spinach sampled over three 24-h periods at the University of Alaska (UAF) in Fairbanks, AK. Lines indicate significant $(P \leq 0.05)$ linear relationships between time and TNC for the light period. An insufficient number of data points exist for linear analysis of TNC over time during the dark period.
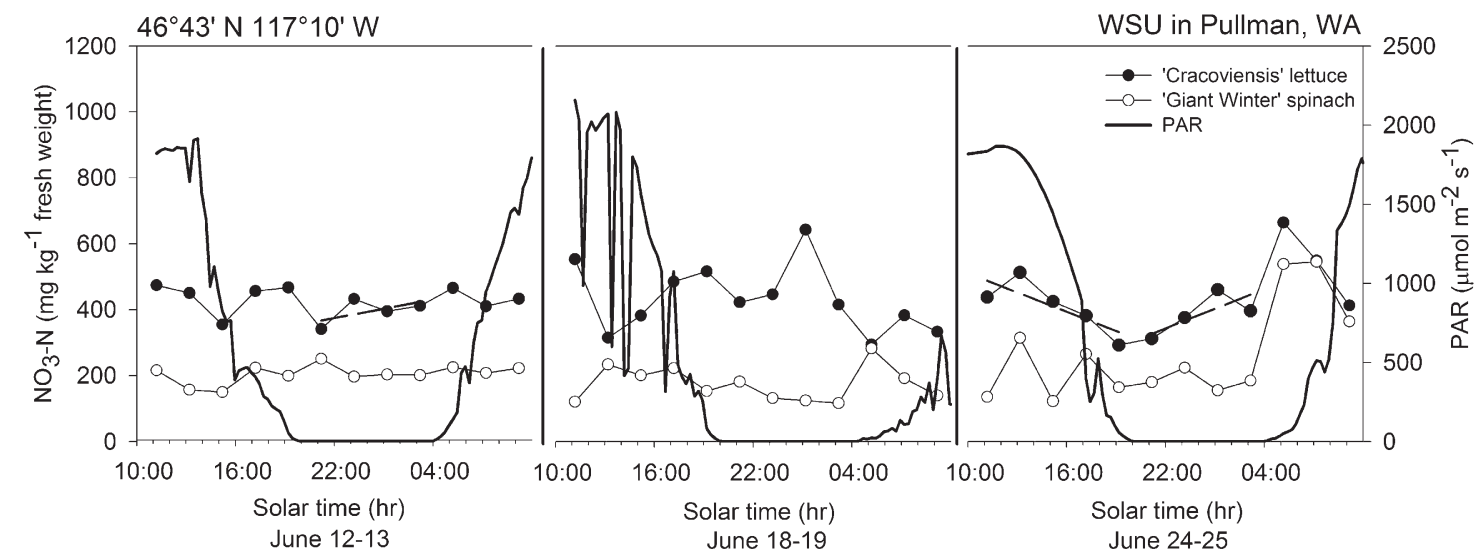

Fig. 2. Variations in photosynthetically active radiation $(P A R)$ and tissue nitrate concentration (TNC) in lettuce and spinach sampled over three 24-h periods at Washington State University (WSU) in Pullman, WA. Lines indicate significant $(P \leq 0.05)$ linear relationships between time and TNC for the period indicated.

values (1400 to $1900 \mu \mathrm{mol} \cdot \mathrm{m}^{-2} \cdot \mathrm{s}^{-1}$; Figs. 1 and 2) measured during summer production at the two latitudes where our study was conducted, which may partially explain the lower TNC in our studies. Also, Cantliffe (1972b) reported that TNC of spinach grown for $12 \mathrm{~h}$ in light of $\approx 500 \mu \mathrm{mol} \cdot \mathrm{m}^{-2} \cdot \mathrm{s}^{-1}$ was $22 \%$ lower than spinach exposed to $6 \mathrm{~h}$ of light at the same intensity, even with relatively high $\mathrm{N}$ fertilizer rates. It is possible that with the longer photoperiods and higher light intensities that were observed in this field study and that occur in the summer at northern latitudes, there was not a sufficient dark period for plants to accumulate nitrate and produce the clear diurnal patterns observed in greenhouse and growth chamber research.

Because harvests did not occur on the same days between the WSU and UAF sites, it is not possible to draw direct comparisons between the two latitudes. Overall, TNC in lettuce appeared to be higher at UAF than at WSU although plant size and soil N conditions were similar between sites. Differences in TNC between sites were generally small for spinach although plants were much smaller at UAF as a result of direct seeding. The longer photoperiod associated with the higher latitude at UAF did not appear to result in lower TNC than at the lower latitude, perhaps because light intensity was lower at UAF than at WSU. At UAF, bolting of lettuce by the 10 July harvest resulted in highly erratic TNC for this sampling date (Fig. 1). At WSU, the presence of cloud cover on 12 June and 18 June (PAR data, Fig. 2) may be responsible for the absence of clear linear trends in TNC during those days for either species at this site. These lower (12 June) or erratic (18 June) light intensities may have reduced nitrate reductase enzyme activity and impacted the linear trends in TNC, which were more common on sunny days.

Overall, the TNC measured in this study was much lower than in controlled environment research and other field studies. A significant factor influencing the TNC in leafy vegetables is fertilizer supply and $\mathrm{N}$ availability (Guadagnin et al., 2005; Maynard et al., 1976). Fertilizer from organic sources typically has a lower $\mathrm{N}$ availability than inorganic $\mathrm{N}$ fertilizer (Gaskell and Smith, 2007) and may be responsible for low TNC observed in this study.

The European Commission has set limits on acceptable concentrations of $\mathrm{NO}_{3}$ in leafy greens depending on crop, harvest time, and method of cultivation (Santamaria, 2006).
According to the European Commission, fresh lettuce and spinach grown in summer under field conditions have maximum permissible nitrate levels of $2500 \mathrm{mg} \mathrm{NO}_{3} / \mathrm{kg}$ fresh weight (565 $\mathrm{mg} \mathrm{NO}-\mathrm{N} / \mathrm{kg}$ fresh weight). In our study, average TNC ranged from 287 to 607 $\mathrm{mg} \mathrm{NO} 3-\mathrm{N} / \mathrm{kg}$ fresh weight for lettuce and 141 to $189 \mathrm{mg} \mathrm{NO}-\mathrm{N} / \mathrm{kg}$ fresh weight for spinach. These concentrations were well below the European Commission limits for spinach and exceeded the limits for lettuce only at UAF on one harvest date.

Spinach generally had lower TNC than lettuce in this study. This is contrary to research indicating that spinach has higher TNC than lettuce (Muramoto, 1999; Roorda van Eysinga, 1984; Santamaria et al., 1999). Amr and Hadidi (2001) measured slightly higher TNC in lettuce than in spinach. Additionally, in a 10-year study in which spinach and lettuce samples were collected from retail markets in Sweden, average $\mathrm{TNC}$ was $600 \mathrm{mg} \mathrm{NO} \mathrm{N}_{3}-\mathrm{N} / \mathrm{kg}$ fresh weight for lettuce and $400 \mathrm{mg} \mathrm{NO}-\mathrm{N} / \mathrm{kg}$ fresh weight for spinach (Merino et al., 2006). However, there is considerable cultivar variation within a species of leafy greens (Cantliffe, 1973; Maynard and Barker, 1974; Ott et al., 2008). For example, when Barker et al. (1974) evaluated 18 cultivars of spinach. they found 
that some cultivars had TNC that was twice as high as other cultivars. Differences in TNC between lettuce and spinach grown in this study were as likely the result of the cultivars selected as the species themselves.

\section{Conclusions}

Our results indicate that although TNC of summer field-grown leafy greens may decline linearly and gradually over time during the day and increase at night, diurnal variation is not as consistent nor is the magnitude of change as great as that reported in controlled-environment studies. Higher light intensities and longer photoperiods during the summer at these latitudes may explain the difference between this field study and controlled-environment research. The TNC and magnitude of diurnal fluctuation should not pose a human health risk regardless of when plants are harvested under these conditions.

\section{Literature Cited}

Amr, A. and N. Hadidi. 2001. Effect of cultivar and harvest date of nitrate $\left(\mathrm{NO}_{3}\right)$ and nitrite $\left(\mathrm{NO}_{2}\right)$ content of selected vegetables grown under open field and greenhouse conditions in Jordan. J. Food Compost. Anal. 14:59-67.

Barker, A.V., D.N. Maynard, and H.A. Mills. 1974. Variations in nitrate accumulation among spinach cultivars. J. Amer. Soc. Hort. Sci. 99:132-134.

Cantliffe, D.J. 1972a. Nitrate accumulation in spinach grown under different light intensities. J. Amer. Soc. Hort. Sci. 97:152-154.

Cantliffe, D.J. 1972b. Nitrate accumulation in vegetable crops as affected by photoperiod and light duration. J. Amer. Soc. Hort. Sci. 97:414-418.

Cantliffe, D.J. 1973. Nitrate accumulation in spinach cultivars and plant introductions. Can. J. Plant Sci. 53:365-367.
Chen, T.M. and S.K. Ries. 1969. Effect of light and temperature on nitrate uptake and nitrate reductase activity in rye and oat seedlings. Can. J. Bot. 47:341-343.

Gaskell, M. and R. Smith. 2007. Nitrogen sources for organic vegetable crops. HortTechnology 17:431-441.

Grindlay, D.J.C. 1997. Towards an explanation of crop nitrogen demand based on the optimization of leaf nitrogen per unit leaf area. J. Agr. Sci. 128:377-396.

Guadagnin, S.G., S. Rath, and F.G.R. Reyes. 2005. Evaluation of the nitrate content in leaf vegetables produced through different agricultural systems. Food Addit. Contam. 22: 1203-1208.

Hageman, R.H., D. Flesher, and A. Gitter. 1961. Diurnal variation and other light effects influencing the activity of nitrate reductase and nitrogen metabolism in corn. Crop Sci. 1:201-204.

Harper, J.E. and G.M. Paulsen. 1968. Influence of intensity, quality, and duration of light on nitrogen reduction and assimilation in wheat. Crop Sci. 8:537-539.

Kaiser, W.M. and S.C. Huber. 2001. Post-translational regulation of nitrate reductase: Mechanism, physiological relevance and environmental triggers. J. Expt. Bot. 52:1981-1989.

Maynard, D.N. and A.V. Barker. 1974. Nitrate accumulation in spinach as influenced by leaf type. J. Amer. Soc. Hort. Sci. 99:135-138.

Maynard, D.N., A.V. Barker, P.L. Minotti, and N.H Peck. 1976. Nitrate accumulation in vegetables. Adv. Agron. 28:71-118.

Merino, L., P.O. Darnerud, U. Edberg, P. Aman, and M.D.P. Castillo. 2006. Levels of nitrate in Swedish lettuce and spinach over the past 10 years. Food Addit. Contam. 23:1283-1289.

Muramoto, J. 1999. Comparison of nitrate content in leafy vegetables from organic and conventional farms in California. Ctr. Agroecol. Sustain. Food Sys. Univ. of California, Santa Cruz. 20 Mar. 2010. <http://envs.ucsc.edu/shennan/Joji/ leafnitrate-1.pdf $>$.
Ott, K.A., R. Koenig, and C. Miles. 2008. Influence of plant part on nitrate concentration in lettuce and spinach. Intl. J. Veg. Sci. 14:351361.

Proietti, S., S. Moscatello, A. Leccese, G. Colla, and A. Batistelli. 2004. The effect of growing spinach (Spinacia oleracea L.) at two light intensities on the amounts of oxalate, ascorbate and nitrate in their leaves. J. Hort. Sci. Biotechnol. 79:606-609.

Roorda van Eysinga, J.P.N.L. 1984. Nitrate in vegetables under protected cultivation. Acta Hort. 145:251-256.

Santamaria, P. 2006. Nitrage in vegetables: Toxicity, content, intake and EC regulation. J. Sci. Food Agr. 86:10-17.

Santamaria, P., A. Elia, F. Serio, and E. Todaro. 1999. A survey of nitrate and oxalate content in fresh vegetables. J. Sci. Food Agr. 79:18821888.

Solomonson, L.P. and M.J. Barber. 1990. Assimilatory nitrate reductase: Functional properties and regulation. Annu. Rev. Plant Physiol. Plant Mol. Biol. 41:225-253.

Steingrover, E., R. Oosterhulis, and F. Wieringa. 1982. Effect of light treatment and nutrition on nitrate accumulation in spinach (Spinacia oleracea L.). Z. Pflanzenphysiol. 107:97-102.

Steingrover, E., P. Ratering, and J. Siesling. 1986. Daily change in uptake, reduction and storage of nitrate in spinach grown at low light intensity. Physiol. Plant. 66:550-556.

Vogtmann, H., A.T. Temperli, U. Künsch, M. Eichenberger, and P. Ott. 1984. Accumulation of nitrates in leafy vegetables grown under contrasting agricultural systems. Biol. Agric. Hort. 2:51-68.

Weightman, R.M., C. Dyer, J. Buxton, and D.S. Farrington. 2006. Effect of light level, time of harvest and position within field on the variability of tissue nitrate concentration in commercial crops of lettuce (Lactuca sativa) and endive (Cichorium endiva). Food Addit. Contam. 23:462-469. 